\title{
СТРАНА ЛЕКСИКА У ЦРНОТРАВСКОМ РЕЧНИКУ РАДОСАВА СТОЈАНОВИЋА: СЕМАНТИЧКА АДАПТАЦИЈА
}

Рад се бави семантичком адаптацијом стране лексике у говору Црне Траве, који припада призренско-тимочкој дијалекатској области. Предмет нашег интересовања јесте оно значење које одређена позајмљеница има и у језику даваоцу и у стандардном српском језику. Циљ рада јесте да се утврди да ли одређена позајмљеница има исто значење и у говору Црне Траве или не. Грађа је преузета из Црнотравског речника Р. Стојановића (2010). На основу спроведене анализе можемо закључити да се у корпусу уочавају четири врсте промена у семантичкој екстензији: нулта семантичка екстензија (потпуно подударање значења модела и реплике), сужење значења реплике у односу на модел, проширење значења реплике у односу на модел и неподударање значења.

Кључне речи: страна лексика, говор Црне Траве, призренско-тимочка дијалекатска област, језик давалац, стандардни српски језик, семантичка адаптација.

\section{1. Увод}

Рад се бави семантичком адаптацијом стране лексике у говору Црне Траве, који припада призренско-тимочкој дијалекатској области. О карактеристикама призренско-тимочке дијалекатске области писали су многи дијалектолози (БЕЛИЋ 1905; ИВИЋ 1985; ВУКАДИНОВИЋ 1996; БОГДАНОВИЋ, МАРКОВИЋ 2000; РЕСО 1985; ОКUКА 2008), о чему је било речи у нашим претходним истраживањима (СТЕВАНОВИЋ 2019; СТЕВАНОВИЋ 2020).

Овај рад се надовезује на наша претходна истраживања (СТЕВАНОВИЋ 2019; СТЕВАНОВИЋ 2020). У мањој мери се ослања на рад Романизми у Црнотравском речнику Радосава Стојановића: семантичка адапmaųja (СТЕВАНОВИЋ 2019). Док се поменути рад бави семантичком адаптацијом романских позајмљеница у говору Црне Траве, овај рад се бави семантичком адаптацијом осталих позајмљеница. Предмет нашег интересо-

\footnotetext{
$\overline{{ }^{1} \text { jovanica.st@gmail.com }}$
} 
вања јесте оно значење које одређена позајмљеница има и у језику даваоцу и у стандардном српском језику. Циљ рада јесте да се утврди да ли одређена позајмљеница има исто значење и у говору Црне Траве или не. Грађа је, као и у споменутом раду, преузета из Црнотравског речника (СТОЈАНОВИЋ 2010). Због ограниченог простора, анализиране су само именице. Биране су само оне именице које означавају нешто неживо (предмет, одећу, храну, пиће, простор, музички инструмент, превозно средство и сл.). Определили смо се за именице које означавају нешто неживо, јер су семантички разноврсније (за разлику од именица које означавају нешто живо које се односе или на носиоца одређене особине или на вршиоца одређене радње), бројније су и пружају богатији материјал за анализу. Значења која имају у језику даваоцу и у стандардном српском језику утврђена су коришћењем неколико речника језика давалаца и српског језика².

\section{2. Претходна истраживања}

О страној лексици у призренско-тимочком дијалекту писали су многи, о чему је било речи у нашим претходним радовима (СТЕВАНОВИТ 2019; СТЕВАНОВИЋ 2020). За потребе овог рада осврнућемо се само на најновија истраживања. А. Јанић је писала о англицизмима (2020), а И. Милошевић о германизмима у жаргону југоисточне Србије (2020). Рад Н. Јовић бави се турцизмима у сточарској терминологији југоисточне Србије (2019), док се рад Б. Марковић бави грецизмима и латинизмима у виноградарској лексици.

Пошто је овај рад наставак претходних истраживања, споменућемо и рад Семантичка адаптација стране лексике у говорима призренско-тимочке дијалекатске области (СТЕВАНОВИЋ 2020). У споменутом раду грађа је преузета из следећих дијалекатских речника: Речник говора јабланичког краја Р. Жугић, Речник села Каменице код Ниша В. Јовановића и Додатак Речнику села Камениче код Ниша В. Јовановића. Анализирани корпус обухвата 43 позајмљенице, које су подељене у три групе: нулта семантичка екстензија, сужење значења реплике у односу на модел и проширење значења реплике у односу на модел (СТЕВАНОВИЋ 2020: 433-434). У анализираном корпусу бројчано доминирају турцизми и германизми. У већем броју су забележени и романизми. Грецизми су забележени у мањој мери, као и хунгаризми и англицизми (СТЕВАНОВИЋ 2020: 433).

\footnotetext{
${ }^{2}$ Списак коришћених речника дат је на крају рада.
} 


\section{3. Семантичка адаптација стране лексике у говору црне траве}

Семантичком адаптацијом стране лексике бавио се мали број лингвиста. Хоуп (Норе) указује на сужење значења реплике, али примећује да се оно може и проширити уколико реплика у језику примаоцу добије нова значења која модел нема (POPOVIĆ 2005: 116).

Са друге стране, семантичком адаптацијом бавио се и Р. Филиповић који је највише пажње посветио променама у семантичкој екстензији (СТЕВАНОВИЋ 2019: 202). Бавећи се променама у семантичкој екстензији, Филиповић разликује: нулту семантичку екстензију (потпуно подударање значења модела и реплике), сужење значења реплике у односу на модел (броја значења и значењског поља) и проширење значења реплике у односу на модел (броја значења и значењског поља) (1986: 65-67; POPOVIĆ 2005: 116; СТАНКОВИЋ 2016: 129; СТЕВАНОВИЋ 2019: 202).

Променама у семантичкој екстензији бавио се и Мартиновски (Martinowsky). Мартиновски разликује: сужење значења, проширење значења, делимично преклапање значења и неподударање значења (1978: 175176). Ослањајући се на Мартиновског, М. Поповић разликује: подударање значења, сужење значења, проширење значења, делимично преклапање значења и неподударање значења (2005: 118-119).

Методолошки поступак М. Поповића примењујемо и ми у овом раду. За разлику од Поповића који анализира промене значења српске реплике у односу на значење француског модела, ми анализирамо промене значења одређене позајмљенице у призренско-тимочком дијалекту (говору Црне Траве) у односу на значење које одређена позајмљеница има и у језику даваоцу и у стандардном српском језику. Определили смо се за овакву методологију, јер у дијалекатској лексици постоје два страна слоја: старији слој и нова страна лексика (ЋУПИЋ 1984: 198). С тим у вези не можемо са сигурношћу рећи да су се све позајмљенице прво појавиле у стандардном српском језику, па да су из њега преузете у говор Црне Траве. Поједине позајмљенице припадају старијем слоју и преузимане су у време када нисмо имали стандард у данашњем смислу. Грађа је преузета из Црнотравског речника Р. Стојановића који обухвата више од 1000 страна (2010). Анализирани корпус обухвата више од 300 позајмљеница (укључујући и романске позајмљенице о којима је било речи у посебном раду (СТЕВАНОВИЋ 2019)), али смо за потребе овог рада издвојили 47.

Наша анализа значења сваке јединице је показала да се током интегрисања модела у речнички састав говора Црне Траве појављују следеће врсте промена у семантичкој екстензији: нулта семантичка екстензија (потпуно подударање значења модела и реплике), сужење значења реплике у односу на модел, проширење значења реплике у односу на модел, неподударање значења. 
Нулта семантичка екстензија представља потпуно подударање значења модела и реплике (РОРОVIĆ 2005: 116; СТЕВАНОВИЋ 2019: 202; СТЕВАНОВИЋ 2020: 428). Анализирани корпус бележи 83 примера. За потребе овог рада издвајамо један део ${ }^{3}$ :

1) автобус - аутобус - Имаш а́втобус у четúри са́та за Бе́оград 4 (СТОЈАНОВИЋ 2010: 24).

аутобус ${ }^{5}$ - нем. велики путнички аутомобил с већим бројем седишта (РМС 1967a: 110); моторно возило за превоз већег броја путника у јавном саобраћају (КЛАЈН, ШИПКА 2008: 170). der Autobus $^{6}$ - аутобус (POPOVIĆ 2005: 45).

2) вермен - старински прслук извезен ибришимом и срмом (СТОЈАНОВИЋ 2010: 95).

фермен - тур. мушки прслук извезен гајтаном, део турске ношње (КЛАЈН, ШИПКА 2008: 1324); тур. мушки прслук од чохе без рукава, обично украшен гајтанима, који се носи поврх копорана (РМC 1976: 664); тур. дио старе народне ношње, врста прслука, од чохе, кадифе или шијака, извезен гајтанима, сприједа сасвим отворен и не скопчава се (ŠKALJIĆ 1966: 280).

fermene - apx. фермен (прслук од чоје или кадифе, украшен гајтаном) (ĐINĐIĆ, TEODOSIJEVIĆ, TANASKOVIĆ 1997: 363).

3) вилџан - шољица за кафу (СТОЈАНОВИЋ 2010: 100).

филиан, финцан - тур. шољица за кафу без дршке (РМС 1976: 671; РСЈ 2011: 1408); тур. шољица без дршке, обично за црну кафу (КЛАЈН, ШИПКА 2008: 1335); тур. шољица за црну кафу (ŠKALJIĆ 1966: 283).

fincan-шољицазакафу (ĐINIĐIĆ, TEODOSIJEVIĆ, TANASKOVIĆ 1997: 370).

4) вланел - врста платна, фланел - Куде Џúду и́ма јо́ш да се ку́пи влане́л, па си ку́пи и саши́ га́ћке на деца́ (СТОЈАНОВИЋ 2010: 103).

фланел - енгл. лака, мека памучна или вунена тканина (РМС 1976: 676); енгл. мекана, лака памучна или платнена тканина (КЛАЈН, ШИПКА 2008: 1341).

flannel - фланел, платно (PERLIĆ 2015: 109).

5) влаша - флаша - Не́ би му ја́ дала́ да то́лко ло́че, ону́j би му вла́шу од гла́ву разби́ла (СТОЈАНОВИЋ 2010: 104).

\footnotetext{
${ }^{3}$ Позајмљенице наводимо по азбучном реду. Тако и ниже.

${ }^{4}$ Контексте дајемо онда када није дато потпуно објашњење значења одређене позајмљенице. Експираторни акценат из техничких разлога бележимо као дугоузлазни.

${ }^{5}$ Стандарднојезички модел бележимо курзивом.

${ }^{6}$ Модел преузет из одређеног језика подвлачимо.
} 
флаша - нем. стакленка, боца (РМС 1976: 676); нем. боца (КЛАЈН, ШИПКА 2008: 1342); нем. боца, стакленка (РСЈ 2011: 1410). die Flashe - боца, флаша (POPOVIĆ 2005: 139).

6) вронцла - реса, ројта, фронцла (СТОЈАНОВИЋ 2010: 113). фронила - нем. кићанка, реса, ројта (КЛАЈН, ШИПКА 2008: 1366). die Franse - peca (POPOVIĆ 2005: 144); реса, фронцла (JOVANOVIĆ, CIKORA 2003: 114).

7) вруштук - доручак - Увек преско́чи вру́штук, ви́ка удебелúл се, па држи́ дие́ту (СТОЈАНОВИЋ 2010: 116).

фруштук - нем. варв. доручак, зајутрак (РМС 1976: 691); нем. доручак (КЛАЈН, ШИПКА 2008: 1366).

das Frühstück - доручак (JOVANOVIĆ, CIKORA 2003:115; POPOVIĆ 2005: 147).

8) вузбал - 1. фудбалска игра; 2. лопта, фудбалㄱ (СТОЈАНОВИһ 2010: 118).

фудбал - енгл. 1. најпопуларнија игра лоптом, ногомет; 2. фудбалска лопта (КЛАЈН, ШИПКА 2008: 1367).

football - 1. фудбал; 2. фудбалска лопта, фудбал (ERAKOVIĆ 2002: 80 ).

9) ђевђир - цедиљка, посуда са решеткастим дном (СТОЈАНОВИЋ 2010: 205).

Ђевђир - тур. покр. кухињска посуда за цеђење, цедило, цедиљка, цетка (РMC 1967a: 818); перс. цједиљка, бакрена посуда за цијеђење (ŠKALJIĆ 1966: 250); тур. перс. метална посуда за цеђење, цедиљка (КЛАЈН, ШИПКА 2008: 400); тур. кухињска посуда са шупљикавим дном која служи за цеђење, цедило, цетка, цедиљка (РСЈ 2011: 321).

kevgir - рупичаста кашика, цедиља (ĐINĐIĆ, TEODOSIJEVIĆ, TANASKOVIĆ 1997: 588).

10) јексер - ексер - Напраи́л вра́та без јексе́ри све́ о(д)-дрво (СТОЈАНОВИЋ 2010: 345).

ексер - тур. гвозден клин, чавао (РМС 1967а: 836).

ekser - нар. гвозден клин; велики ексер, чавао (ĐINĐIĆ, TEODOSIJEVIĆ, TANASKOVIĆ 1997: 330).

11) качемак - качамак - Качема́к оста́де на вери́ге у котле́, а ја́ побе́го за мое́га чове́ка. - Спре́ми ми за ју́тре качема́к с ква́сено млеко́ Збркај на брзи́ну качема́к, кьд је већ упа́лен о́гењ (СТОЈАНОВИЋ 2010: 358).

качамак - тур. јело од тврдо скувана кукурузног брашна, пура, жганци, палента (РМС 1967б: 683); тур. врста јела справљена од

\footnotetext{
${ }^{7}$ Исто значење налазимо и у Речнику села Каменице код Ниша. Упоредити са СТЕВАНОВИТ 2020: 433.
} 
кукурузна брашна, пура (ŠKALJIĆ 1966: 377); тур. јело од куваног кукурузног брашна, палента, пура (РСJ 2011: 513).

kaçamak-качамак, пура (ĐINĐIĆ, TEODOSIJEVIĆ, TANASKOVIĆ 1997: 534).

12) киреч - креч - Угаси́мо една́ ко́ла ки́реч (СТОЈАНОВИЋ 2010: 365).

Речници српског језика не бележе ову позајмљеницу.

kirec - креч, вапно (ĐINĐIĆ, TEODOSIJEVIĆ, TANASKOVIĆ 1997: 607).

13) ковер - кофер -Све́ те́ј ства́ри држи́ у ко́вер, пот ката́нац - Спреми́л ко́вер да за Ђурђо́вдьн и́де у рабо́ту (СТОЈАНОВИТ 2010: 375). кофер - нем. тврда правокутна, правоугла кутија (од коже, картона и сл.) с поклопцем који се може закључати, а служи за ношење ствари при путовању, ковчег (РМС 1969: 19); нем. путни ковчег од коже, скаја, тврдог пресвученог картона, дрвета и др., у којем се обично носи одећа и друге потрепштине (РСЈ 2011: 562); нем. путни ковчег, путна торба (КЛАЈН, ШИПКА 2008: 674).

der Koffer - кофер, путнички ковчег (POPOVIĆ 2005: 211).

14) панађур - вашар - Спремúл се, и́де 3-ба́бу на панађу́р у Власо́тинци (СТОЈАНОВИЋ 2010: 628).

nанађур - тур. вашар, пазар, сајам (КЛАЈН, ШИПКА 2008: 889); сајам, вашар (PMC 1971: 317); тур. вашар (ŠKALJIĆ 1966: 509).

panayir - панађур, вашар; сајам (ĐINĐIĆ, TEODOSIJEVIĆ, TANASKOVIĆ 1997: 773).

15) сокак - улица у селу - Обли́та по сока́ци; не сме́је до́м да до́јде, да га не ру́жу за неки́ па́кос (СТОЈАНОВИЋ 2010: 878).

сокак - тур. мања, узана улица, уличица (КЛАЈН, ШИПКА 2008: 1160). sokak - сокак, (уска) улица (ĐINĐIĆ, TEODOSIJEVIĆ, TANASKOVIĆ 1997: 878).

16) тарана - 1. резанци од теста; 2. јело од резанаца од теста (СТОЈАНОВИЋ 2010: 916).

тарана - тур. кулин. 1. осушено, измрвљено зрнасто тесто; 2. супа припремљена са таквим тестом (КЛАЈН, ШИПКА 2008: 1217); издробљено тијесто на мрвице у облику зрнаца и осушено, од чега се прави истоимена супа (ŠKALJIĆ 1966: 601).

tarhana - кул. 1. тархана (измрвљено и осушено тесто које се користи за припремање јела); 2. чорба од таране (ĐINĐIĆ, TEODOSIJEVIĆ, TANASKOVIĆ 1997: 939).

17) чекија - бритва, ножић који се склапа у корице, чакија (СТОЈАНОВИЋ 2010: 1020).

чакија - тур. покр. џепни ножић с оштрицом која се склапа, перорез (КЛАЈН, ШИПКА 2008: 1462); џепни ножић, перорез (ŠKALJIĆ 1966: 160). 
çaki- - чакија, џепни нож (ĐINĐIĆ, TEODOSIJEVIĆ, TANASKOVIĆ 1997: 199).

18) штемез - клесарска алатка, штемајзл - Тój са́мо са ште́мез мо́ж да се располу́ти (СТОЈАНОВИЋ 2010: 1052).

штемајзл - нем. покр. заст. длето (КЛАЈН, ШИПКА 2008: 1501); нем. варв. оруђе за дубење у дрвету и камену, длето (РМС 1976: 1006). das Stemmeisen - длето (POPOVIĆ 2005: 362).

Сужење значења реплике у односу на модел представља промену која подразумева да реплика има уже значење од модела (POPOVIĆ 2005: 119; СТЕВАНОВИТ 2019: 204; СТЕВАНОВИЋ 2020: 430). Сужење значења се може остварити смањењем броја значења или значењског поља (POPOVIĆ 2005: 116). Анализирани корпус бележи 201 пример. Издвајамо један део:

19) амбар - дрвена зграда за чување жита (СТОЈАНОВИЋ 2010: 32). амбар - перс. 1. дрвена зграда за зрнасту храну, житарица, силос; 2. сандук за жито и брашно; 3. доњи дио кафеног млина, гдје пада самљевена кафа (ŠKALJIĆ 1966: 92-93); тур. 1. дрвена зграда за зрнасту храну; сандук за жито и брашно; 2 . преграда у води подешена за хватање рибе; доњи део млина за кафу у који пада самлевена кафа; 3. дрвена зграда у којој се смешта зимница; 4. преграда у којој се у дућанима држало брашно, рижа и сл. (ЕРСЈ 2003: 144); тур. 1 . остава за зрнасту храну; 2. нарочито ограђено место у води за хватање рибе (РМС 1967а: 73).

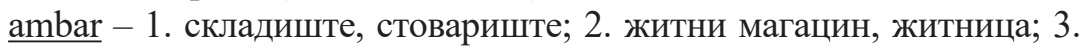
бродско складиште, товарни простор брода; 4. мера, врећица од 75 цм (за песак, шљунак и сл.); 5. шпедитерска компанија, шпедитерско предузеће (ĐINĐIĆ, TEODOSIJEVIĆ, TANASKOVIĆ 1997: 45).

20) анџар - ханџар, велики нож - Ка(д)-до́вати анџа́р, па изле́зе мани́т пред њи́, да ги поко́ље (СТОЈАНОВИЋ 2010: 33).

ханиар - тур. дуг закривљен нож или кратак мач, са две оштрице (КЛАЈН, ШИПКА 2008: 1380); тур. нож савијеног облика, ношен у корицама за појасом; врста старинске сабље (РМС 1976: 711); ар. дуги (70-80) шиљати нож, с оштрицом с обадвије стране. Понекад ханџаром називају и кратки криви мач или јатаган (ŠKALJIĆ 1966: 310).

hançer - ханџар, јатаган (ĐINĐIĆ, TEODOSIJEVIĆ, TANASKOVIĆ 1997: 443).

21) вистан - посебна врста сукње, шарена сукња, фистан - У Дерве́н же́не но́су ви́стани и кана́вци (СТОЈАНОВИЋ 2010: 102).

фистан - тур. 1. женска сукња; 2. мушка народна ношња у облику сукње (КЛАЈН, ШИПКА 2008: 1338); тур. женска сукња, мушка народна ношња у облику сукње (ŠKALJIĆ 1966: 284). 
fistan - 1. фистан, сукња; 2. шкотска сукња (мушка) (ĐINĐIĆ, TEODOSIJEVIĆ, TANASKOVIĆ 1997: 371).

22) ренде - кухињска направа за стругање поврћа (СТОЈАНОВИЋ 2010: 819).

ренде - тур. 1. направа на којој се стругањем ситни поврће, воће, сир (купус, кромпир, јабука, тврди сир и сл.); треница; 2. дрводељска алатка за стругање дрвета; блања (КЛАЈН, ШИПКА 2008: 1066); тур. 1. кухињска направа за стругање поврћа и теста, треница, рибеж. 2. дрводељска справа за стругање, струг, блања (РСJ 2011: 1134).

rende - 1. стругало, стругача; 2. ренде, блања; 3. отирак, изрибак (ĐINĐIĆ, TEODOSIJEVIĆ, TANASKOVIĆ 1997: 810).

23) саџак - метални троножни држач посуда за кување (СТОЈАНОВИЋ 2010: 837).

саиак - тур. 1. жељезни троножац на коме се на огњишту у тенџери или каквом другом суду вари јело; 2. троножац уопште (ŠKALJIĆ 1966: 540-541).

saçayak - 1. троножац (за котао); 2. фиг. триумвират (ĐINĐIĆ, TEODOSIJEVIĆ, TANASKOVIĆ 1997: 820).

24) симиче - дем. од симит - Увек ку́пи по неко́ симиче́ да донесе́ до́м (СТОЈАНОВИЋ 2010: 849).

симит - тур. врста малог округлог хлеба од белог брашна (РМС 1973: 764); тур. врста малог округлог куповног (пекарског) хљеба од бијелог брашна (ŠKALJIĆ 1966: 565); тур. мали округли хлеб од белог брашна (РСJ 2011: 1197); тур. хлеб који се меси од најфинијег пшеничног брашна; мали округли хлеб од белог брашна (КЛАЈН, ШИПКА 2008: 1139).

$\underline{\text { simit }}$ - 1. симит (округао колач од белог хлеба); ђеврек; 2. мор. (округли) појас за спасавање; 3. арг. нула, кромпир (оцена у школи); 4. фино пшенично брашно (ĐINĐIĆ, TEODOSIJEVIĆ, TANASKOVIĆ 1997: 871)

25) скамлија - ђачка клупа, скамија - Седе́ли смо по четúри ђа́ка у скамли́jу (СТОЈАНОВИЋ 2010: 852).

скамија - грч. клупа уопште, школска клупа (РМC 1973: 795; РСЈ 2011: 1204).

skamvi - 1. клупа, клупица (без наслона); 2. оптуженичка клупа (БАЛАЋ, СТОЈАНОВИЋ 2009: 635).

\footnotetext{
${ }^{8}$ Овај пример налазимо и у рукописној збирци речи Димитрија Чемерикића која је писана у првој половини 20. века. Упоредити са ПЕТРОВИТ 2012: 258. Са друге стране, налазимо га и у роману Нечиста крв Боре Станковића. Упоредити са ТОМИЋ 2015: 248. Реч симит забележена је и у Вуковом рјечнику (1818: 761). На основу свега реченог можемо закључити да је овај пример преузет у време када нисмо имали стандард у данашњем смислу, односно да је преузет из језика даваоца (турског језика).
} 
26) сурла - пеј. нос, велики нос - Наду́ла су́рле не́ће с ме́не (да) ора́ти - Mópe, треба́ло-е да му рашчу́кам ону́ј су́рлу ка-це ра́здра на ме́не (СТОЈАНОВИЋ 2010: 910).

сурла - тур. 1. а. издужени меснати део њушке у слона и неких других животиња који служи као орган за дисање, пипање, осећај мириса и хватање; б. издужени предњи део главе многих тврдокрилаца, који им служи за бушење, сисање и сл., рилица; 2. фиг. подр. нос (обично упадљиво велик, дугачак) (РС 2011: 1268; РМС 1976: 100).

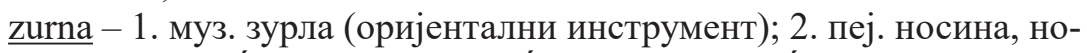
сурда (ĐINĐIĆ, TEODOSIJEVIĆ, TANASKOVIĆ 1997: 1093).

27) тевтер - бележница - Све́ úмам у те́втер коú ми ко́лко дугу́је још од ла́њску го́дину - Те́втер ће ка́же све́, кво́ úма да се льжемо (СТОЈАНОВИТ 2010: 918).

тефтер - тур. 1. бележница, списак, записник; 2. рачунска, трговачка књига (КЛАЈН, ШИПКА 2008: 1244); биљежница, регистар, протокол; рачунска књига; трговачка књига дуговања и потраживања (ŠKALJĆ 1966: 606); тур. бележница, записник, регистар, протокол; трговачка књига примања и издавања, рачунска књига (РМС 1976: 200).

defter - 1. свеска; 2. трговачка књига, дефтер; регистар; списак, попис (ĐINĐIĆ, TEODOSIJEVIĆ, TANASKOVIĆ 1997: 253).

28) тулум - мешина за држање вина - Пронесо́ше ракиџи́је ви́но и раки́ју у тулуми́ (СТОЈАНОВИЋ 2010: 941).

тулум - тур. 1. мешина (за вино и другу течност); 2. празноглав човек, тупан (РМС 1976: 333); тур. 1. мешина; 2. фиг. празне главе, неспособан човјек (ŠKALJÍ́ 1966: 622-623).

tulum - 1. мешина; 2. муз. мешина, мешница, гајде; 3. туба (за пасту за зубе); 4. раднички комбинезон, зеке (дечије оделце) (ĐINĐIĆ, TEODOSIJEVIĆ, TANASKOVIĆ 1997: 987).

29) туршија - укисељено поврће за зиму (СТОЈАНОВИЋ 2010: 943). mуршија - тур. воће и поврће ушчувано за зиму у води, пресолцу и сирћету (РМС 1976: 346); тур. нарочито справљена зимница од воћа и поврћа у пресолцу и сирћету (РСJ 2011: 1326).

tursu - 1. туршија, укисељено воће или поврће; 2. киселица, киселиш (ĐINĐIĆ, TEODOSIJEVIĆ, TANASKOVIĆ 1997: 989).

30) ћемане - виолина - Доне́л у рабо́ту ћема́не, па ни учи́л да сви́римо (СТОЈАНОВИТ 2010: 946).

ћемане - тур. виолина (РМС 1976: 360); тур. виолина (КЛАЈН, ШИПКА 2008: 1291); перс. виолина (ŠKALJĆ 1966: 188); тур. врста гудачког инструмента, виолина (РС 2011: 1329).

$\underline{\mathrm{keman}}-1$. виолина; 2. арх. лук; 3. танак, извијен као лук (о обрва- 
ма) (ĐINĐIĆ, TEODOSIJEVIĆ, TANASKOVIĆ 1997: 580)9.

31) ћенар - 1. чипка - Ко́лко са́м са́мо попле́ла ћенарú за кошу́ље, па за ву́те, за ја́стучнице, па ћенарú с мани́стра рáзне му́стре за плетенче́; 2. ћенар на уљеви - чипка са шпицевима (СТОЈАНОВИЋ 2010: 946).

ћенар - тур. 1. крај, граница, ивица, руб; крај, крајина; 2. врста танког памучног платна украшеног на ивицама; 3 . врста простирке, мањи ћилим којим се застиру крајеви собе (РМС 1976: 360); тур. 1. крај, ивица; 2. врста танког платна; 3 . врста веза на пешкиру (КЛАЈН, ШИПКА 2008: 1291); перс. 1. руб, околица, ивица, крај, прикрајак, маргиналија књиге; 2. крај, крајина, периферија; 3. врста простирке: уско ћилимче, струка, која се простире по крајевима собе да покрије празнине које ћилим није покрио; 4. врста веза, памучног платна, који има околицу, односно знак на рубовима, те одјећа од танког веза (ŠKALJIĆ 1966: 189).

kenar - 1. крај, ивица, руб, маргина; 2. страна; 3. обала; 4. бордура, перваз (марамице и сл.) (ĐINĐIĆ, TEODOSIJEVIĆ, TANASKOVIĆ 1997: 581).

32) ћумез - фиг. запуштена, тесна просторија ${ }^{10}$ - Да не уле́знеш у онúja ћуме́з (СТОЈАНОВИЋ 2010: 949).

ћумез - тур. 1. живинарник за кокоши, кокошињац; 2. запуштен, влажан и прљав стан или крчма (РМС 1976: 368).

kümes -1 . кокошарник, живинарник; 2. фиг. кућерак, потлеушица (ĐINĐIĆ, TEODOSIJEVIĆ, TANASKOVIĆ 1997: 649).

33) цуг - гутљај - Не да́вај на ње́га да први пи́је, úма голе́м цу́г (СТОЈАНОВИЋ 2010: 1014).

иуг - нем. варв. 1. парни воз, влак, железница; 2. промаја, пропух; 3. поворка; 4. мања чета, вод; 5. гутљај, гуцај (РМС 1976: 828); нем. 1. воз, железница; 2. потез; 3. у некадашњој аустроугарској војсци најмања јединица с немачким службеним језиком; вод 4. промаја, пропух; 5. поворка, колона; 6. а. појединачно повлачење чега у неком раду или послу; потез. б. гутљај; 7. механизам за подизање декора и завеса на сцени; 8. врста велике удице за лов на сомове (КЛАЈН, ШИПКА 2008: 1460-1461).

der Zug - кретање, поворка, јато; воз; потез, црта; гутљај; особина, својство; промаја (POPOVIĆ 2005: 499).

34) чајче, чајченце, чајчьк - дем. и хип. од чај - Ћу ти сва́рим зача́с чајчьк о(д)-ди́вљи џо́џан, да ти про́јде мешúна - Ел ти вика́ ће ти

\footnotetext{
9 Исти је случај као и са примером симит. Упоредити са ПЕТРОВИЋ 2012: 286; ТОМИЋ 2015: 249.

${ }^{10}$ Исто значење налазимо и у Речнику села Каменице код Ниша В. Јовановића. Упоредити са СТЕВАНОВИТ 2020: 430.
} 
помо́гне чајче́ од ками́лицу - Да ти сва́рим чајче́нце, да не дрћеш то́лко (СТОЈАНОВИЋ 2010: 1015).

чај - тур. в. чајевац 1. азијска биљка из које се добија чај; 2. напитак од те биљке; 3. напитак од осушених цветова, листова, корена или плодова различитих биљака (КЛАЈН, ШИПКА 2008: 1462).

çay - 1. чај, бот. чајево дрво; 2. чајанка, чај партија (ĐINĐIĆ, TEODOSIJEVIĆ, TANASKOVIĆ 1997: 210).

35 ) чанче - дем. од чанак, земљана, дрвена чинија (СТОЈАНОВИЋ 2010: 1016).

чанак - тур. 1. а. здела, чинија за јело (обично дрвена); б. здела или кутија у којој се држи ситан новац; 2. у старинској пушци кремењачи место где се сипа барут, прашник; 3. кориташце испод воденичког коша из којега жито пада на жрвањ (РМС 1976: 838; PCJ 2011: 1471).

çanak - 1. чанак, (глинена) посуда, здела а) глинене посуде, грнчарија; б) кухињска посуда, кухињски прибор; 2. бот. чашица (цвета); 3. анат. чашица (бубрежна); 4. тех. чашица; 5. геог. котлина, удолина; 6. леген, лавор, умиваоник (ĐINĐIĆ, TEODOSIJEVIĆ, TANASKOVIĆ 1997: 203).

36) шербет - вода заслађена врелим шећером (СТОЈАНОВИЋ 2010: 1043). шербе, шербет - тур. сладак топао напитак од упрженог шећера куваног с водом; уопште сладак напитак од воде с медом или шећером, медовина (РСЈ 2011: 1503); тур. слатко пиће од воде с медом или шећером, медовина; сладак напитак од упрженог шећера куваног с водом (РМС 1976: 943); тур. 1. напитак од упрженог шећера с водом; 2. источњачко освежавајуће пиће од воде с медом и зачинима; 3. узаврела вода за кување кафе (КЛАЈН, ШИПКА 2008: 1486). serbet - 1. шербет; 2. раствор; 3. фарм. сируп (ĐINĐIĆ, TEODOSIJEVIĆ, TANASKOVIĆ 1997: 914).

37) шићер - шећер - У со́бу уле́же на коња́ и шиће́р му да́де, и на́поље па́ изле́же, то́лко васпи́тан ко́њ, и по́еде они́ја шиће́р (СТОЈАНОВИТ 2010: 1045).

шећер - тур. 1. биол. хем. органско хемијско једињење из групе угљених хидрата, кристалног облика и слатког укуса, растворљиво у води, један од честих биљних састојака и важан елеменат исхране; 2. производ од прерађене шећерне трске или шећерне репе који служи за заслађивање, сахароза; 3. (у придевској служби, у полусложеницама) шећеран, сладак; фиг. умиљат, леп (обично у нар. песмама) (РМС 1976: 948).

seker - 1. шећер; 2. шећерлема, бомбона; слаткиш, посластица; 3. шећерна болест, дијабетес (ĐINĐIĆ, TEODOSIJEVIĆ, TANASKOVIĆ 1997: 913). 
38) шприц - прскалица, штрцаљка - Напраúла деца́ шпрúц од бáз, па и ме́не ушприца́ше с во́ду (СТОЈАНОВИЋ 2010: 1051).

uприц - нем. варв. мед. 1. прибор у облику стакленог цилиндра с клипом и шупљом иглом за убризгавање лекова под кожу, у мишиће, вене и сл. бризгалица; 2. шприцаљка, прскалица (РМС 1976: 998); нем. 1. мед. прибор у облику стакленог или пластичног цилиндра с клипом и шупљом иглом за убризгавање течних лекова под кожу, у мишиће или вене, бризгалица. 2. шприцаљка, прскалица, шмрк (РС 2011: 1518).

die Spritze - штрцаљка, бризгалица, шмрк; инјекција (POPOVIĆ 2005: 356).

Проширење значења реплике у односу на модел представља развој неких нових значења у дијалекту којих нема у језику даваоцу или у стандардном српском језику. Ово није чест тип семантичке адаптације. Најчешће се шири или број значења или значењско поље. Анализирани корпус обухвата 11 примера (укључујући и романске позајмљенице о којима је било речи ${ }^{11}$ ):

39) буклија - кондир којим се позива на свадбу или славу - Појдо́мо 3-букли́ју у ро́д да ги ви́камо на сва́дбу (СТОЈАНОВИЋ 2010: 82). буклија - грч. пљоснат дрвени суд, чутура, пљоска (РМС 1967а: 300; КЛАЈН, ШИПКА 2008: 244); грч. мањи пљоснат дрвени суд за вино или ракију, пљоска; чутура (РСJ 2011: 114). mpoûklion $^{12}$ - пљоска (БАЛАЋ, СТОЈАНОВИЋ 2009: 471) ${ }^{13}$.

40) пенџер - 1. прозор, стакло на прозору; 2. мн. наочаре ${ }^{14}$ - Чиú-е тúja ма́ли с пе́нџери? - Игра́л се, па му деца́ разби́ла пе́нџери (СТОЈАНОВИЋ 2010: 637).

пениер - тур. прозор (РМС 1971: 384; РСЈ 2011: 907); тур. заст. и покр. прозор (КЛАЈН, ШИПКА 2008: 926); перс. прозор (ŠKALJIĆ 1966: 515).

pencere - прозор (ĐINĐIĆ, TEODOSIJEVIĆ, TANASKOVIĆ 1997: 785).

41) таламбас - 1. бубањ, тупан; 2. бука, галама - Што́-е па́ тако́j páно ди́гал таламбасú? (СТОЈАНОВИЋ 2010: 914)

таламбас - тур. мали метални бубањ чинијастог облика преко чијег је отвора разапета кожа (КЛАЈН, ШИПКА 2008: 1212); тур. врста малог старинског бубња, метална здела са разапетом кожом преко отвора (РМС 1976: 133); тур. врста бубња (у виду мање ме-

\footnotetext{
11 Упоредити са СТЕВАНОВИЋ 2019: 206-207.

${ }^{12}$ Овај облик упоредити са КЛАЈН, ШИПКА 2008: 244.

13 У речницима српског и грчког језика није наглашено чему служи буклија.

14 Значење наочаре није забележено ни у Речнику села Каменице код Нища В. Јовановића ни у Речнику говора јабланичког краја Р. Жугић. Упоредити са СТЕВАНОВИЋ 2020: 430.
} 
талне зделе са разапетом кожом преко отвора) (РCJ 2011: 1276). davlumbaz $^{15}$ - apx. бубањ, таламбас (ĐINĐIĆ, TEODOSIJEVIĆ, TANASKOVIĆ 1997: 251).

42) ћуп - 1. земљани врч, крчаг; 2. фиг. глава - Ел úма нешто́ у овúја ћу́п, ел пра́зан sавнú? (СТОЈАНОВИЋ 2010: 949)

ћyn - тур. земљани дубоки суд с ужим грлом, крчаг, врч (КЛАЈН, ШИПКА 2008: 1294).

küp - ћуп (за пекмез, масло и сл.) (ĐINĐIĆ, TEODOSIJEVIĆ, TANASKOVIĆ 1997: 649).

43 ) чантра - 1. кожна ташна; 2. кутија за ситан алат; 3. посуда у којој косач носи брус (СТОЈАНОВИЋ 2010: 1016).

чанта, чантра - тур. кожна торба (КЛАЈН, ШИПКА 2008: 1463). çanta - торба, ташна (ĐINĐIĆ, TEODOSIJEVIĆ, TANASKOVIĆ 1997: 204).

У вези са неподударањем значења М. Поповић пише следеће: „U procesu značenjske adaptacije nekih reči semantemi replike i semantemi modela toliko su se udaljili da se njihova značenja ne podudaraju ni u jednom kontekstu" (2005: 146). У неким случајевима у процесу значењске адаптације нестала је веза између садржине модела и садржине реплике или је у питању погрешна интерпретација садржине модела (2005: 119). Удаљавање значења између модела и реплике утврђује се на дијахронијској равни пошто је значењска веза нестала у процесу интеграције модела. Са друге стране, „на синхронијској равни модел и реплика могу поседовати неки заједнички сем, но он је нерелевантан за њихове семантеме узете у целини" (2005: 147). Анализирани корпус бележи четири примера неподударања значења модела и реплике:

44) кубе - ваљкаста, плехана пећ - Накла́ди до́бро то́ј ку́бе, едну́ш да се згре́јемо како тре́бе (СТОЈАНОВИЋ 2010: 403).

кубе - тур. полулоптасти свод на врху грађевина, купола (КЛАЈН, ШИПКА 2008: 683); полулоптасти свод, обично на врху већих јавних грађевина (најчешће цркава), купола (РСЈ 2011: 594); ap. 1. свод, купола; 2. кружни дио капка на млину за кафу (ŠKALJIĆ 1966: 421).

kubbe - кубе, купола; свод (ĐINĐIĆ, TEODOSIJEVIĆ, TANASKOVIĆ 1997: 633).

$45)$ паламар - 1. калемарски нож; 2. фиг. позамашан комад нечега Гађа́л ме с ово́лки палама́р; 3. фиг. мушки полни уд (СТОЈАНОВИЋ 2010: 627).

паламар - тур. 1. дебело бродско уже, гумина; 2. клин, чавао (РМС 1971: 308); тур. дебело бродско уже (РС 2011: 893); тур. 1. уже

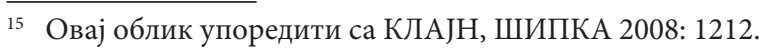


којим се везују бродови за обалу, гумина; 2. дебео гвоздени клин (КЛАЈН, ШИПКА 2008: 885); тур. дебело уже којим се брод веже за обалу (ŠKALJIĆ 1966: 508).

palamar - мор. уже, канап (за привезивање бродова) (ĐINĐIĆ, TEODOSIJEVIĆ, TANASKOVIĆ 1997: 772).

46) таратор - фиг. неред, гужва ${ }^{16}$ - Бе́гајте си до́м, напраúли сте ми тарато́р по ку́ћу (СТОЈАНОВИЋ 2010: 917).

таратор - тур. додатак јелу, салата од киселог млека, свежих краставаца и белог лука (РМС 1976: 149); тур. салата од ситно сецканих краставаца, белог лука, киселог млека, уља и соли (КЛАЈН, ШИПКА 2008: 1218).

tarator - кул. мезе које се прави од средине хлеба, ораха, маслиновог уља, белог лука и сирћета (ĐINĐIĆ, TEODOSIJEVIĆ, TANASKOVIĆ 1997: 938).

47) чадор - фиг. кишобран - Мо́ж ли сви́ да ста́немо по(д)-тújа ча́дор, да ни не умо́кри (СТОЈАНОВИЋ 2010: 1015).

чадор - тур. 1. шатор; 2. женска одећа у неким исламским земљама, која обавија читаво тело осим дела лица, понекад и читаво лице (КЛАЈН, ШИПКА 2008: 1462); тур. 1. шатор, шатра; 2. велики вео или огртач којим муслиманке у Ирану и суседним земљама прекривају лице (РСJ 2011: 1470); тур. шатор (PMC 1976: 834; ŠKALJIĆ 1966: 159). çadir - шатор, чадор, јурта (ĐINĐIĆ, TEODOSIJEVIĆ, TANASKOVIĆ 1997: 197).

Споменуте примере треба прокоментарисати. На основу објашњења из речника и контекста из Црнотравског речника можемо закључити да је у свим случајевима дошло до померања значења. Наиме, модел и реплика поседују неки заједнички сем, али је он нерелевантан за њихове семантеме узете у целини. Семантичка веза између реплике чадор и модела çadir постоји (покривање), као и између реплике паламар и модела palamar (позамашно, велико). Са друге стране, семантичка веза постоји и између реплике таратор и модела tarator (мешавина нечега), као и између реплике кубе и модела kubbe (облик). Споменути примери припадају старијем лексичком слоју (ПЕТРОВИЋ 2012; ЂИНЪИЋ 2013), што говори у прилог томе да су преузети из језика даваоца (турског језика), а не из стандардног српског језика.

\section{4. Закључак}

$\mathrm{y}$ анализираном корпусу бројчано доминирају турцизми (амбар, аниар, вермен, вилцан, вистан, Ђевђир, јексер, качемак, киреч, кубе, пала-

\footnotetext{
${ }_{16}$ Значење неред, гужва не налазимо у Речнику говора јабланичког краја Р. Жугић. Упоредити са СТЕВАНОВИТ 2020: 429.
} 
мар, панађур, пениер, ренде, саиак, симиче, сокак, сурла, таламбас, тарана, таратор, тевтер, тулум, туршија, ћемане, ћенар, ћумез, ћуп, чадор, чајче/чајченще/чајчьк, чанче, чантра, чекија, шербет, иићер). У већој мери су забележени и германизми, али смо за потребе овог рада издвојили осам (автобус, влаша, вронила, вруштук, ковер, иуг, шприи, штемез). Остале позајмљенице забележене су у мањој мери (англицизми (вланел, вузбал) и грецизми (буклија, скамлија)).

Страну лексику из анализираног корпуса можемо поделити у четири групе: 1) нулта семантичка екстензија; 2) сужење значења реплике у односу на модел; 3) проширење значења реплике у односу на модел; 4) неподударање значења. Нулта семантичка екстензија обухвата много примера, али смо за потребе овог рада издвојили 18 (автобус, вермен, вилиан, вланел, влаша, вронила, вруштук, вузбал, ђевђир, јексер, качемак, киреч, ковер, панађур, сокак, тарана, чекија, штемез). Сужење значења реплике у односу на модел обухвата, такође, много примера, али смо за потребе овог рада издвојили 20 (амбар, анцар, вистан, ренде, саиак, симиче, скамлија, сурла, тевтер, тулум, туршија, ћемане, ћенар, ћумез, иуг, чајче/чајченце/ чајчьк, чанче, шербет, шићер, шприи). Проширење значења реплике у односу на модел обухвата мали број примера (буклија, пениер, таламбас, ћуn, чантра). Неподударање значења обухвата четири примера (кубе, паламар, таратор, чадор).

Као и претходна два истраживања (СТЕВАНОВИЋ 2019; СТЕВАНОВИЋ 2020), и ово истраживање је показало да су нулта семантичка екстензија и сужење значења реплике у односу на модел два честа типа семантичке адаптације. Треба напоменути да је сужење значења реплике у односу на модел чешћи тип семантичке адаптације. По М. Поповићу, „strana reč se pozajmljuje da bi se zadovoljila potreba za imenovanjem određenog pojma te se od više značenja modela preuzima samo ono koje zadovoljava tu potrebu" (2005: 124). Дакле, уколико говорник Црне Траве жели да именује одређени референт, од језика даваоца или од стандардног српског језика узима само оно значење које му је потребно за именовање тог референта.

За разлику од претходних горепоменутих истраживања, ово истраживање је показало да понекад може доћи до неподударања значења. Неподударање значења је редак тип семантичке адаптације, о чему говори анализирани корпус који обухвата само четири примера. Понекад долази до померења значења. Наиме, веза између значења модела и значења реплике постоји, односно модел и реплика поседују неки заједнички сем, али он није релевантан за њихове семантеме узете у целини.

Проширење значења реплике у односу на модел је веома редак тип семантичке адаптације, о чему говори анализирани корпус који обухвата само 11 примера (укључујући и романске позајмљенице). Пошто се позајмљеница интегрише у говор Црне Траве, она шири или број значења или значењ- 
ско поље, о чему говори анализирани корпус.

Шта се намеће као закључак? Прво - да говор Црне Траве више тежи ка сужењу, него ка проширењу. Друго - да говор Црне Траве више тежи ка поклапању, него ка непоклапању значења.

\section{Цитирана литература}

БЕЛИЋ, Александар. „Дијалекти источне и јужне Србије”. Српски дијалектолошки зборник I, (1905): стр. 1-715.

БОГДАНОВИЋ, Недељко и МАРКОВИЋ, Јордана. Практикум из дијалектологије. Ниш: Филозофски факултет, 2000.

ВУКАДИНОВИЋ, Вилотије. „Говор Црне Траве и Власине”. Српски дијалектолошки зборник XLII, (1996): стр. 1-317.

ЂИНЂИЋ, Марија. Туричими у савременом српском књижевном језику (семантичко-деривациона анализа). Београд: Филолошки факултет (докторска дисертација), 2013.

ИВИЋ, Павле. Дијалектологија српскохрватског језика: увод и штокавско наречје. Нови Сад: Матица српска, 1985.

ЈАНИЋ, Александра. „Англицизми у жаргону југоисточне Србије”. Исходишта 6, (2020): стр. 109-127.

ЈОВИЋ, Надежда. „Турцизми у сточарској терминологији југоисточне Србије”. Исходишта 5, (2019): стр. 221-236.

МАРКОВИЋ, Бранкица. „Грецизми и латинизми у виноградарској лексици”. Исходишта 6, (2020): стр. 191-201.

МИЛОШЕВИЋ, Ивана. „Германизми у Речнику жаргонизама јужне пруге”. Годишъак за српски језик 18, (2020): стр. 21-34.

ПЕТРОВИЋ, Снежана. Туричзми у српском призренском говору. На материјалу из рукописне збирке речи Димитрија Чемерикића. Београд: Институт за српски језик САНУ, 2012.

СТАНКОВИЋ, Селена. „Француске позајмљенице у говорима југоисточне Србије: семантичка адаптација”. У Селена Станковић (Ур.), Франиуско-српске лингвистичке паралеле (стр. 123-143). Ниш: Филозофски факултет, 2016.

СТЕВАНОВИЋ, Јована. „Романизми у Црнотравском речнику Радосава Стојановића: семантичка адаптација”. У Марина Јањић (Ур.), Савремени токови у науции о језику и књижевности (стр. 197-210). Ниш: Филозофски факултет, 2019.

СТЕВАНОВИЋ, Јована. „Семантичка адаптација стране лексике у говорима призренско-тимочке дијалекатске области". У Јасмина Шаранац Стаменковић, Љиљана Скробић, Мирјана Илић, Милена Каличанин (Ур.), Нови правции истраживања у друштвеним и хуманистичким наукама (стр. 423-437). Ниш: Филозофски факултет, 2020. 
СТЕФАНОВИЋ КАРАЏИЋ, Вук. Српски рјечник истолкован њемачким и латинским ријечима. <http://digital.bms.rs/ebiblioteka/pageFlip/reader/index> 20.02.2021.

ТОМИЋ, Драгана. „Турцизми у роману Нечиста крв Борисава Станковића”. Годишьак Учительског факултета у Врању књ.VI, (2015): 243-257.

ЋУПИЋ, Драго. „Туђице у дијалекатској лексици и њихова обрада”. Лексикографија и лексикологија, (1984): стр. 197-201.

FILIPOVIĆ, Rudolf. Teorija jezika u kontaktu: uvod u lingvistiku jezičnih dodira. Zagreb: Jugoslavenska akademija znanosti i umjetnosti - Školska knjiga, 1986.

MARTINOWSKY, Georges. „L'évolution sémantique en russe des emprunts au francais et au vocabulaire international spécialisé. Recherche de métode". Revue des Etudes slaves 51/1-2, (1978): 171-179.

OKUKA, Miloš. Srpski dijalekti. Zagreb: SDK Prosvjeta, 2008.

PECO, Asim. Pregled srpskohrvatskih dijalekata. Beograd: Naučnaknjiga, 1985.

POPOVIĆ, Mihailo. Reči francuskog porekla u srpskom jeziku. Beograd: Zavod za udžbenike i nastavna sredstva, 2005.

\section{Речниции}

БАЛАЋ, Александар и СТОЈАНОВИЋ, Миодраг. Грчко-српски речник. Београд: Завод за уџбенике и наставна средства, 2009.

ЕРСЈ: Етимолошки речник српског језика Свеска 1: А. Београд: Институт за српски језик САНУ, 2003.

КЛАЈН, Иван и ШИПКА, Милан. Велики речник страних речи и израза. Треће допуњено и исправљено издање. Нови Сад: Прометеј, 2008.

PMC: Речник српскохрватскога књижевног језика. I-III. Нови Сад - Загреб: Матица српска - Матица хрватска, 1967-1969.

PMC: Речник српскохрватскога књижевног језика. IV-VI. Нови Сад: Матица српска, 1971-1976.

PCJ: Речник српскога језика. Измењено и поправљено издање. Нови Сад: Матица српска, 2011.

ĐINĐIĆ, Slavoljub, TEODOSIJEVIĆ, Mirjana i TANASKOVIĆ, Darko. TürkçeSirpça Sözlük. Ankara: Türk Dil Kurumu, 1997.

ERAKOVIĆ, Borislava. Rečnik englesko-srpski, srpsko-engleski. Novi Sad: Liber; Kruševac: Teatar Za, 2002.

JOVANOVIĆ, Zora i CIKORA, Agota. Ilustrovani nemačko-srpski rečnik. Novi Sad: Zmaj: Atlantis; Podgorica: Zavod za izdavanje udžbenika i nastavna sredstva, 2003.

PERLIĆ, Nenad. Englesko-srpski rečnik sa izgovorom. <https://www.scribd.com/ doc/283134121/Englesko-srpski-Recnik-Sa-Izgovorom> 23.02.2021. 
POPOVIĆ, Milan. Rečnik nemačko-srpski i srpsko-nemački: (sa gramatikom nemačkog jezika). Zemun: JRJ; Niš: Prosveta, 2005.

ŠKALJIĆ, Abdulah. Turcizmi u srpskohrvatskom jeziku. Sarajevo: Svjetlost, 1966.

Извор

СТОЈАНОВИЋ, Радосав. „Црнотравски речник”. Српски дијалектолошки зборник LVII, (2010): 1-1060.

Jovana S. Stevanović

\section{FOREIGN LEXICON IN THE DICTIONARY OF CRNA TRAVA BY RADOSAV STOJANOVIĆ: THE SEMANTIAL ADAPTATION}

The paper deals with the semantial adaptation of foreign lexicon in the speech of Crna Trava, which belongs to the Prizren-Timok dialect area. The subject of our interest is the knowledge that a certain borrower has both in the giving language and in the standard Serbian language. The aim of this paper is to determine whether a certain loanword has the same meaning in the speech of Crna Trava or not. The material is taken from the Dictionary of Crna Trava by R. Stojanović (2010). Based on the analysis, we can conclude that four types of changes in semantic extension are observed in the corpus: zero semantic extension (complete matching of model and replica meanings), narrowing of replica meaning in relation to model, expansion of replica meaning in relation to model, meaning unmatching.

Keywords: foreign lexicon, the speech of the Crna Trava, the Prizren-Timok dialectal area, the giving language, the standard Serbian language, the semantial adaptation. 